\title{
PERTUMBUHAN TANAMAN KETAPANG (Terminalia catappa L) DENGAN PENAMBAHAN PUPUK ORGANIK DAN NPK PADA TAILING DI PERSEMAIAN
}

(The Growth of Terminalia catappa L with the organic and NPK fertilizer on tailing media in nursery)

\author{
Eka Musrini, Abdurrani Muin, Burhanuddin \\ Fakultas Kehutanan Universitas Tanjungpura Jalan Daya Nasional Pontianak 78124 \\ Email : ekamusrini1978@gmail.com
}

\begin{abstract}
Restoration and revegetation must be done to recover the post-mining land ecosystem. The strategy of one vegetative that could be applied to rehabilitate degraded the post-mining land is revegetation with the applications the organic and NPK fertilizer to improve the land conditions and choose the suitable of the plant. Terminalia catappa $L$ is one of the plants classified as a pioneer species and can grow on the poor nutrient land and easy to cultivation. Research on the additions of cow dung as ameliorant and NPK fertilizer to improve the physical, chemical, and biological of tailings media in nursery to the growth of Terminalia catappa L. Treatment was given to the growth of seedlings of Terminalia catappa L using the Completely Randomized Design (RAL) with 2 (two) factor treatment. The first factor is NPK Fertilizer with 5 level treatment such as without Fertilizer (K0), $5 \mathrm{gr}(\mathrm{K} 1), 10 \mathrm{gr}(\mathrm{K} 2), 15 \mathrm{gr}(\mathrm{K} 3), 20 \mathrm{gr}(\mathrm{K} 4)$. The second factor is an organic compound from cow dung with 5 level treatment such us without cow dung (P0), $10 \mathrm{gr}(\mathrm{P1}), 20 \mathrm{gr}(\mathrm{P2}), 30 \mathrm{gr}(\mathrm{P3}), 40 \mathrm{gr}(\mathrm{P} 4)$. Each level of treatment consisting of 3 replications so the amount of seedlings in this research is 75 seedlings. Data collected were short high ( $\mathrm{cm})$, stem diameter ( $\mathrm{mm})$, number of leaves and dry weight of the plant. The result of addition organic and NPK fertilizer on tailing media in nursery gave a significant effect on the growth of height, diameter, number of leaves and dry weight of Terminalia catappa L. The best result media treatment for all parameters is NPK fertilizer and cow dung with combination 20: $40 \mathrm{gr}$, although almost all of the ameliorant treatment gave the better result if compare the control treatment without addition organic ameliorant.
\end{abstract}

Keywords: ameliorant, organic and NPK Fertilizer, Tailings, Terminalia catappa L.

\section{PENDAHULUAN}

Kabupaten Sambas sejak dahulu dikenal sebagai tempat penambangan emas dimulai sejak abad 18 dan 19 oleh imigran Cina yaitu Monterado. Penambangan dilakukan oleh masyarakat setempat dengan cara pendulangan dan penambangan sedot semprot. Kegiatan pertambangan selalu mempunyai dua dampak yang saling berlawanan, di satu sisi dapat mendatangkan keuntungan secara ekonomi namun di sisi lain juga dapat mengakibatkan kerusakan lingkungan.
Kerusakan lingkungan akibat aktivitas penambangan telah menimbulkan dampak negatif yaitu lahan pascatambang menjadi miskin hara, nilai $\mathrm{pH}$ rendah, tanah bersifat toksik karena kandungan logam berat, kapasitas menahan air rendah, kandungan bahan organik rendah dan kondisi lahan tidak stabil. Dampak negatif lainnya terjadi terhadap lingkungan adalah penurunan kondisi tanah bekas penambangan (tailing) berupa hilangnya profil lapisan tanah, dan pemadatan tanah (tingginya tingkat bulk density), kekurangan unsur hara penting, 
$\mathrm{pH}$ rendah, pencemaran oleh logam-logam berat pada lahan bekas tambang, serta penurunan populasi mikroba tanah (Setyaningsih 2007; Tamin 2010; Rusdiana et al. 2010).

Restorasi dan revegetasi merupakan hal yang wajib dilakukan pada lahan bekas penambangan. Strategi rehabiltasi lahan bekas tambang emas antara lain dapat dilakukan dengan memperbaiki kondisi tanah dengan menambah bahan amelioran, memilih jenis tanaman, membuat bibit, menanam dan memelihara. Revegetasi menjadi kegiatan yang wajib dilakukan pada lahan penambangan, namun seringkali upaya revegetasi menghadapi kendala yang cukup berat. Keberhasilan revegetasi pada lahan yang didominasi tailing membutuhkan jenis tanaman yang mampu beradaptasi.

Salah satu jenis tanaman yang bisa digunakan tersebuat adalah tanaman ketapang (Terminalia cattapa) yang berpotensi bila ditanam di daerah kering seperti lahan tailing (Direktorat Perbenihan Tanaman Hutan 2001). Tanaman Ketapang (Terminalia catappa) termasuk salah satu tanaman yang dapat tumbuh di tanah yang kurang nutrisi dan tersebar hampir diseluruh wilayah Indonesia sehingga mudah untuk dibudidayakan. Biji tanaman Ketapang diketahui memiliki kandungan minyak yang cukup tinggi, yaitu sebesar 56,78\% (Ezeokonkwo, 2004) .

Kegiatan revegetasi juga membutuhkan pertumbuhan tanaman yang cepat dan harus disertai dengan upaya perbaikan sifat tanah tailing agar dapat menghasilkan produktivitas tanaman yang baik. Salah satu strategi yang dapat diterapkan pada lahan tailing menurut Ang (1994) adalah dengan ameliorasi bahan organik. Ameliorasi bahan organik berperan dalam memperbaiki stabilitas agregat tanah, meningkatkan daya pegang air, meningkatkan kapasitas tukar kation tanah, menyediakan karbon untuk kehidupan mikroorganisme tanah dan sebagai sumber hara. Penggunaan amelioran merupakan salah satu upaya untuk merubah tailing menjadi lebih produktif, beberapa penelitian menunjukkan pupuk organik meningkatkan efisiensi pemberian pupuk anorganik yang pada gilirannya dapat menunjang produksi yang maksimal. Oleh karena itu dalam penelitian ini, digunakan amelioran pupuk organik yaitu pupuk kandang dari kotoran sapi dan penggunan pupuk anorganik NPK sebagai penambah unsur hara untuk meningkatkan pertumbuhan tanaman dan memperbaiki sifat kimia tanah tailing.

Penelitian ini mendukung restorasi lahan pascatambang emas perlu dilakukan dengan menggunakan tanaman produktif. Sehingga penelitian dapat menjawab permasalahan lingkungan yang timbul akibat industri pertambangan sekaligus dapat meningkatkan ekonomi dari segi pemanfaatan tanaman. Oleh karena itu restorasi tailing menggunakan tamanan ketapang dengan memanfaatkan pupuk organik kotoran sapi dan pupuk NPK perlu dilakukan penelitian atau kajian.

Penelitian ini dilakukan karena semakin meluasnya lahan bekas tambang sebagai lahan yang tidak lagi produktif/miskin unsur hara yaitu dengan adanya perlakuan penambahan pupuk NPK 
dan pupuk organik. Perlakuan tersebut ialah dengan pencampuran pupuk NPK dan pupuk organik ke media tailing untuk mendapatkan perlakuan yang terbaik. Diduga dengan adanya pencampuran jenis pupuk NPK dan pupuk organik pada tailing akan memberikan pertumbuhan tanaman ketapang terbaik yang nantinya akan digunakan sebagai rujukan dalam memperbaiki lahan bekas tambang.

\section{METODELOGI PENELITIAN}

Penelitian ini dilaksanakan selama 3 bulan yaitu pengujian perbaikan media tailing dengan penambahan amelioran. Penelitian ini dilaksanakan di Badan Lingkungan Hidup Kabupaten Sambas, dengan lokasi pengambilan sampel tailing di lokasi Pertambangan Emas Tanpa Izin (PETI) di sekitar Sungai Seminis Kecamatan Tebas Kab. Sambas.

Perlakuan yang diberikan terhadap pertumbuhan bibit ketapang menggunakan metode experimen dengan bentuk rancangan acak lengkap (RAL). Perlakuan

HASIL DAN PEMBAHASAN

\section{Tinggi Bibit Ketapang}

Tinggi bibit ketapang ditentukan berdasarkan hasil pengukuran umur tanaman 12 minggu setelah penyapihan dengan mengukur bibit dari pangkal batang sampai titik tumbuh tanaman. Hasil sidik ragam menunjukkan bahwa perlakuan penambahan NPK memperlihatkan terdiri dari dua faktor dimana sebagai faktor pertama adalah pupuk NPK dengan takaran tanpa pupuk ( K0), $5 \mathrm{~g}$ ( K1), $10 \mathrm{~g}$ (K2), $15 \mathrm{~g}$ (K3), dan $20 \mathrm{~g}$ (K4), dan sebagai faktor kedua adalah Pupuk Organik berupa kotoran sapi; tanpa pupuk (P0), $10 \mathrm{~g}$ (P1), 20g (P2),30 g (P3), dan $40 \mathrm{~g}$ (P4). Masingmasing perlakuan diulang sebanyak 3 kali, sehingga jumlah bibit dalam percobaan ini adalah 75 Data yang dikumpulkan berupa tinggi bibit $(\mathrm{cm})$, diameter bibit $(\mathrm{mm})$, jumlah daun (helai) dan biomassa tanaman (g). Seluruh data dianalisis menggunakan SAS IX yang merujuk pada (Gaspersz, 1991) yang telah disesuaikan dengan rancangan penelitian.

Berdasarkan perhitungan analisis keragaman, maka nilai F.Hit > dari Sig. $0,000(0,05 \%$ pada tarif uji $5 \%)$ berarti berpengaruh nyata. Perlakuan yang berpengaruh nyata dan sangat nyata selanjutnya dilakukan uji berganda Duncan atau Beda Nyata Jujur (Gespersz, 1991).

pengaruh yang sangat nyata terhadap penambahan tinggi bibit ketapang pada media tailing, sementara itu perlakuan faktor penambahan pupuk organik (kotoran sapi) dan faktor interaksinya dengan pupuk NPK tidak menunjukkan pengaruh yang nyata. Hasil uji lanjut berjarak Duncan untuk melihat dosis pupuk NPK yang berbeda, ditunjukkan pada Gambar 1 . 


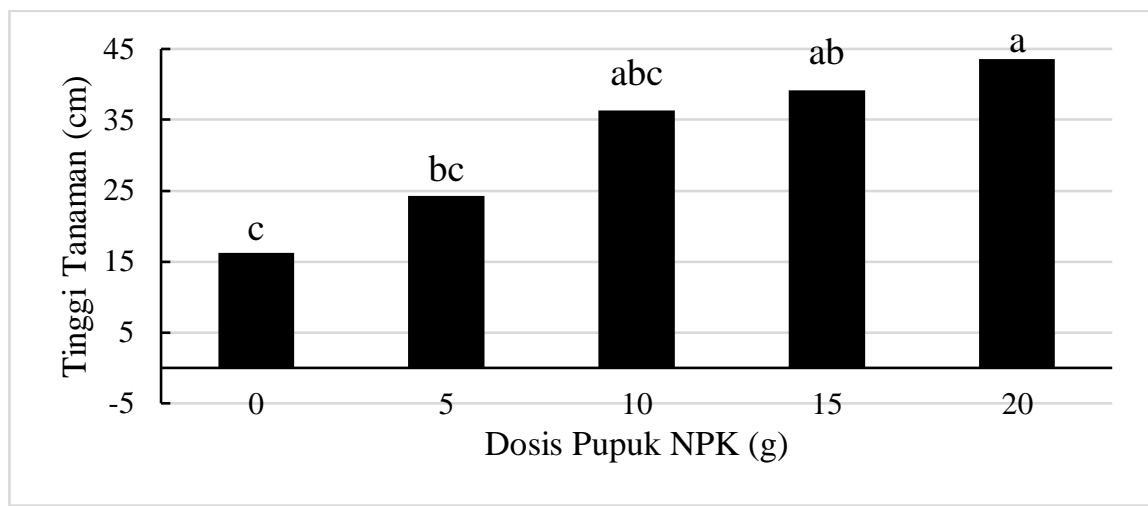

Gambar 1. Pengaruh pupuk NPK terhadap tinggi tanaman Ketapang umur 12 minggu setelah sapih (Effwct of dosage of NPK fertilizers to T. catappa L shoot height at 12 weeks after weaning).

Keterangan : Huruf yang sama pada histogram tidak berbeda nyata berdasarkan uji jarak berganda Duncan taraf $5 \%$. $\mathrm{K}_{0}=0 \mathrm{~g}, \mathrm{~K}_{1}=5 \mathrm{~g}, \mathrm{~K}_{2}=10 \mathrm{~g}, \mathrm{~K}_{3}=15 \mathrm{~g}, \mathrm{~K}_{4}=$ $20 \mathrm{~g}$.

Berdasarkan grafik pada Gambar 1 menunjukkan bahwa dosis pupuk NPK $20 \mathrm{~g}$ berbeda nyata dibandingkan dengan dosis pupuk NPK $0 \mathrm{~g}$ dan dosis pupuk NPK 5 g terhadap pertumbuhan tinggi tanaman ketapang, namun tidak menunjukkan perbedaan dengan dosis pupuk NPK $10 \mathrm{~g}$ dan $15 \mathrm{~g}$. Terjadi peningkatan pertumbuhan tinggi ketapang dengan penambahan dosis pupuk NPK mulai dosis pupuk $10 \mathrm{~g}$. Pemberian dosis pupuk NPK $20 \mathrm{~g}$ dapat meningkatkan pertambahan tinggi ketapang sebesar 169,26 \% dibandingkan dengan tanpa pupuk NPK.

Berdasarkan hasil penelitian Zein dan Zahrah (2015) bahwa perlakuan terbaik pada lidah buaya (Aloe barbadensis Mill.) adalah pemberian sekam padi 4 ton/ha dan pupuk NPK 16:16:16 sebanyak 20 gr/tanaman dengan hasil berat basah tanaman sebanyak 810,83 gr/tanaman dengan persentase peningkatan hasil sebesar
76,27\% dibandingkan tanpa pemberian sekam padi dan pupuk NPK 16:16:16. Lebih lanjut menurut Kamaludin (2017) hasil pengukuran dan penghitungan diketahui bahwa perlakuan yang terbaik dalam memacu pertambahan jumlah daun dan tinggi anakan Salam adalah T4 (Kompos Kotoran Sapi dengan dosis 450 gram per anakan) dengan rerata pertambahan jumlah daun sebanyak 17,40 helai dan rerata pertambahan tinggi $15,00 \mathrm{~cm}$. Penelitian tersebut membuktikan semakin banyaknya jumlah kotoran sapi/pupuk organik yang diberikan memberikan pengaruh yang signifikan terhadap pertumbuhan tanaman.

\section{Diameter bibit ketapang}

Diameter bibit ketapang ditentukan berdasarkan hasil pengamatan pengukuran umur tanaman 12 minggu setelah penyapihan dengan mengukur pada batas pangkal batang menggunakan kaliper digital (mm). Berdasarkan tabel 
hasil sidik ragam menunjukkan bahwa perlakuan dan faktor pemupukan NPK memberikan pengaruh yang sangat nyata terhadap pertambahan diameter bibit ketapang pada media tailing. Perlakuan penambahan pupuk organik menunjukkan pengaruh nyata, namun interaksi antara kedua pupuk tersebut tidak berpengaruh nyata terhadap pertumbuhan diameter. Selanjutnya dilakukan uji lanjut berjarak Duncan untuk melihat dosis pupuk NPK dan pupuk organik (kotoran sapi) yang berpengaruh terhadap pertumbuhan diameter bibit ketapang pada media tailing.

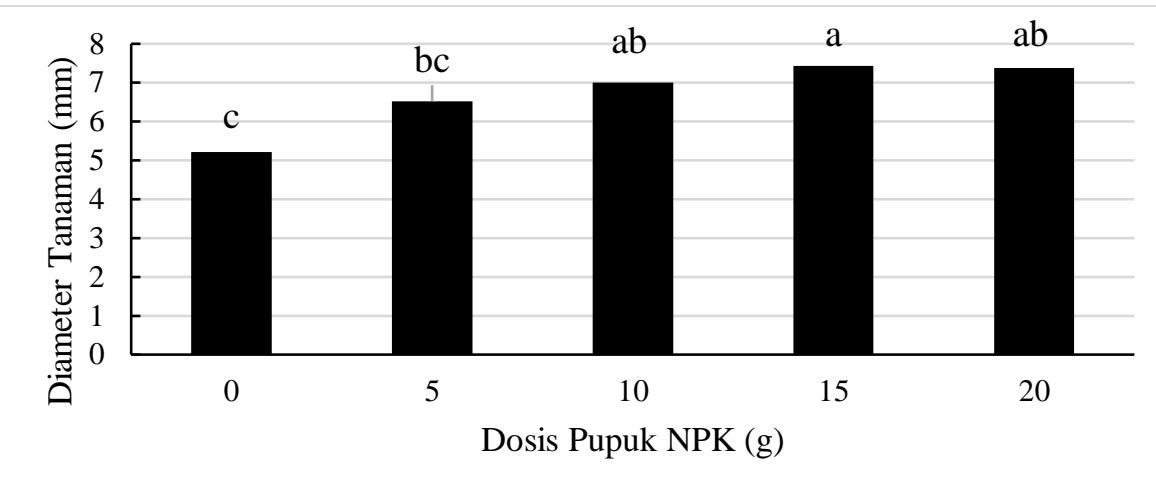

Gambar 2. Pengaruh pupuk NPK terhadap diameter tanaman Ketapang umur 12 minggu setelah sapih (Effwct of dosage of NPK fertilizers to T. catappa L stem diameter at 12 weeks after weaning).

Keterangan : Huruf yang sama pada histogram tidak berbeda nyata berdasarkan uji jarak berganda Duncan taraf $5 \% . \mathrm{K}_{0}=0 \mathrm{~g}, \mathrm{~K}_{1}=5 \mathrm{~g}, \mathrm{~K}_{2}=10 \mathrm{~g}, \mathrm{~K}_{3}=15 \mathrm{~g}, \mathrm{~K}_{4}=20$ g.

Pada grafik Gambar 2 bahwa dosis pupuk NPK $20 \mathrm{~g}, 15 \mathrm{~g}, 10 \mathrm{~g}, 5 \mathrm{~g}$ dan $0 \mathrm{~g}$ tidak memberikan perbedaan yang nyata pada setiap dosis pupuk NPK yang diberikan kepada tanaman ketapang. Terjadi peningkatan pertumbuhan diameter ketapang dengan penambahan dosis pupuk NPK. Pemberian dosis pupuk NPK 15 g dapat meningkatkan pertambahan diameter ketapang sebesar 42,80 \% dibandingkan dengan dosis pupuk NPK 0 g, dan Pemberian dosis NPK 15 g merupakan pemberian dosis yang terbaik dalam meningkatkan pertambahan diameter tanaman ketapang. 


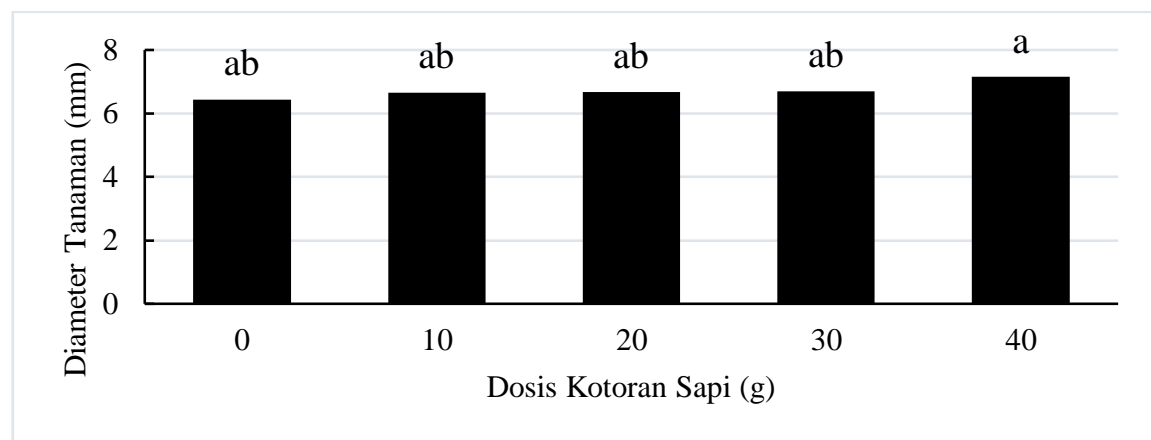

Gambar 3. Pengaruh pupuk kotoran sapi terhadap diameter tanaman ketapang pada media tailing umur 12 minggu setelah sapih (Effect of ameliorant to T. catappa L for steam diameter at 12 weeks after weaning)

Keterangan : Huruf yang sama pada histogram tidak berbeda nyata berdasarkan uji jarak berganda Duncan taraf $5 \%$. $\mathrm{K}_{0}=0 \mathrm{~g}, \mathrm{~K}_{1}=10 \mathrm{~g}, \mathrm{~K}_{2}=20 \mathrm{~g}, \mathrm{~K}_{3}=30 \mathrm{~g}, \mathrm{~K}_{4}=$ $40 \mathrm{~g}$.

Dosis kotoran sapi berdasarkan Gambar 10, 40 g, 30 g, 20 g, 10 g dan 0 $\mathrm{g}$ tidak memberikan perbedaan yang nyata pada setiap dosis kotoran sapi yang diberikan kepada tanaman ketapang. Akan terjadi terjadi peningkatan pertumbuhan diameter ketapang dengan penambahan dosis kotoran sapi. Pemberian dosis kotoran sapi $40 \mathrm{~g}$ dapat meningkatkan pertambahan diameter ketapang sebesar 11,18\% dibandingkan dengan dosis kotoran sapi 0 g. Gambar 3 dan 4 dapat diketahui bahwa perlakuan yang terbaik ialah dengan perbandingan pupuk NPK dan kotoran sapi 20:40 g.

\section{Jumlah Daun Bibit Ketapang}

Jumlah daun ketapang ditentukan berdasarkan hasil pengamatan pengukuran umur tanaman 12 minggu setelah disapih dengan menghitung jumlah daun mulai dari daun pertama sampai daun yang ada pada titik tumbuh yang dilakukan di lokasi penelitian.

Hasil sidik ragam menunjukkan bahwa perlakuan dan faktor pemupukan NPK memberikan pengaruh yang sangat nyata terhadap pertambahan parameter jumlah daun bibit ketapang sedangkan perlakuan faktor penambahan pupuk organik dan faktor interaksi antara pupuk NPK dan pupuk organik tidak memberikan pengaruh yang nyata. Selanjutnya dilakukan uji lanjut berjarak Duncan untuk melihat perlakuan yang berbeda. 


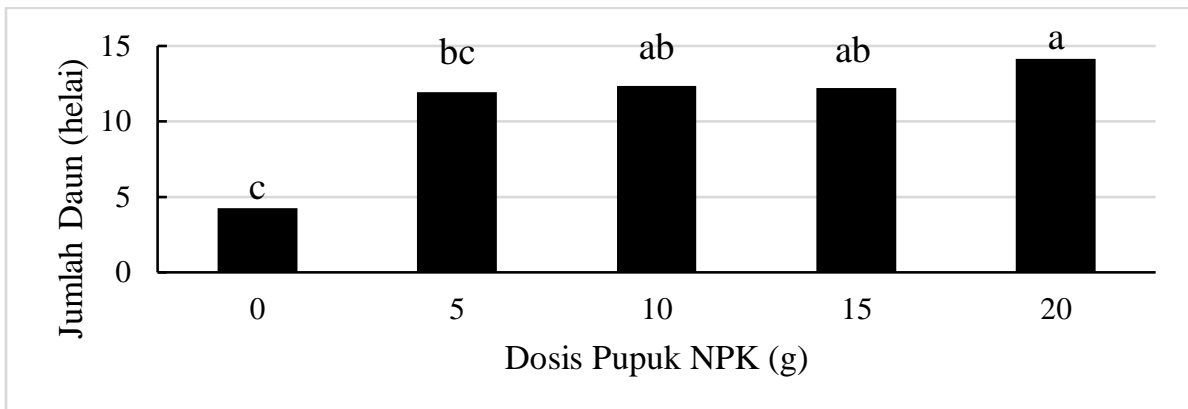

Gambar 4. Pengaruh pupuk NPK terhadap jumlah daun tanaman Ketapang umur 12 minggu setelah sapih (Effwct of dosage of NPK fertilizers to T. catappa L number of leaves at 12 weeks after weaning).

Keterangan : Huruf yang sama pada histogram tidak berbeda nyata berdasarkan uji jarak berganda Duncan taraf $5 \%$. $\mathrm{K}_{0}=0 \mathrm{~g}, \mathrm{~K}_{1}=5 \mathrm{~g}, \mathrm{~K}_{2}=10 \mathrm{~g}, \mathrm{~K}_{3}=15 \mathrm{~g}, \mathrm{~K}_{4}=$ $20 \mathrm{~g}$.

Gambar 4 menunjukan bahwa dosis pupuk NPK $20 \mathrm{~g}$ berbeda nyata terhadap kontrol tailing dosis pupuk NPK $0 \mathrm{~g}$ dan dosis pupuk NPK $5 \mathrm{~g}$, sedangkan dosis pupuk NPK 20 g tidak memberikan perbedaan terhadap dosis pupuk NPK 10 $\mathrm{g}$ dan $15 \mathrm{~g}$. Terjadi peningkatan pertumbuhan ketapang dengan penambahan dosis pupuk NPK. Pemberian dosis pupuk NPK $20 \mathrm{~g}$ dapat meningkatkan pertambahan jumlah daun tanaman ketapang sebesar 230,91\%

dibandingkan dengan dosis pupuk NPK 0 g. Berdasarkan hasil analisis ragam, bahwa interaksi pupuk NPK dan kotoran sapi tidak berpengaruh nyata.

\section{Berat Kering (biomassa) Bibit Ketapang}

Bobot kering bibit ketapang ditentukan berdasarkan hasil pengukuran umur tanaman 12 minggu setelah disapih bibit dari alam dengan pemanenan seluruh tanaman. Seluruh tanaman di oven selama 72 jam pada suhu $68 \%{ }^{\circ} \mathrm{C}$.

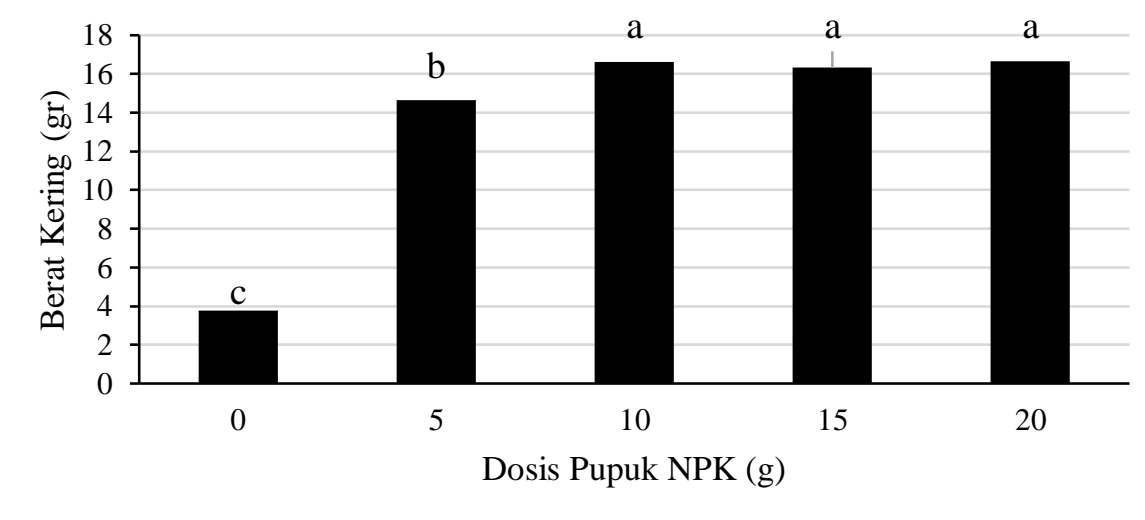

Gambar 5. Pengaruh pupuk NPK terhadap berat kering tanaman Ketapang umur 12 minggu setelah sapih (Effwct of dosage of NPK fertilizers to T. catappa L for shoots dry weight at 12 weeks after weaning).

Keterangan : Huruf yang sama pada histogram tidak berbeda nyata berdasarkan uji jarak berganda Duncan taraf $5 \%$. $\mathrm{K}_{0}=0 \mathrm{~g}, \mathrm{~K}_{1}=5 \mathrm{~g}, \mathrm{~K}_{2}=10 \mathrm{~g}, \mathrm{~K}_{3}=15 \mathrm{~g}, \mathrm{~K}_{4}=20$ g. 
Gambar 5 diatas menunjukan bahwa dosis pupuk NPK $20 \mathrm{~g}$ berbeda nyata terhadap kontrol tailing dosis pupuk NPK $0 \mathrm{~g}$ dan dosis pupuk NPK $5 \mathrm{~g}$. Akan tetapi dosis pupuk NPK $20 \mathrm{~g}$ tidak memberikan perbedaan terhadap dosis pupuk NPK $10 \mathrm{~g}$ dan $15 \mathrm{~g}$. Terjadi peningkatan biomassa ketapang dengan penambahan dosis pupuk NPK. Pemberian dosis pupuk NPK $20 \mathrm{~g}$ dapat meningkatkan pertambahan tinggi ketapang sebesar 342,82 \% dibandingkan dengan dosis pupuk NPK $0 \mathrm{~g}$.

Semua perlakuan tailing memberikan gambaran yang bervariasi pada setiap perlakuan, akan tetapi dari semua hal tersebut ada beberapa perlakuan yang terbaik baik dari penambahan tinggi, diameter, jumlah daun dan berat kering tanaman ketapang. Beberapa perlakuan yang terbaik ialah perlakuan dengan penambahan pupuk NPK dan kotoran sapi 10:0, pupuk NPK dan kotoran sapi 10:40, pupuk NPK dan kotoran sapi 15:10, pupuk NPK dan kotoran sapi 15:20, pupuk NPK dan kotoran sapi 15:30, pupuk NPK dan kotoran sapi 20:20, pupuk NPK dan kotoran sapi 20:40 dibandingkan dengan perlakuan yang lainnya. Sehingga untuk pengaplikasian penanaman dosis pupuk yang terbaik digunakan ialah menggunakan pupuk NPK dan kotoran sapi 20:40 dan jika ditinjau dari segi ekonomisnya maka yang terbaik adalah pupuk NPK dan kotoran sapi 10:0. Dengan penambahan dosis pupuk NPK tanpa pemberian kotoran sapi.
Pemupukan adalah salah satu kegiatan dalam budidaya tanaman yang bertujuan untuk meningkatkan ketersediaan unsur hara bagi tanaman. Ketersediaan unsur hara di dalam tanah sangat mempengaruhi pertumbuhan tanaman, jika terjadi defisiensi unsur hara akan dapat menyebabkan pertumbuhan tanaman terganggu. Berdasarkan hasil analisis data parameter yang diukur yaitu tinggi tanaman, diameter tanaman, jumlah daun tanaman dan berat kering tanaman, membuktikan bahwa bibit ketapang yang ditambahkan dengan pupuk NPK $20 \mathrm{~g}$ pada media bibit dapat meningkatkan pertumbuhan bibit ketapang. Menurut Zein dan Zahrah (2015) bahwa perlakuan terbaik pada lidah buaya (Aloe barbadensis Mill.) adalah pemberian sekam padi 4 ton/ha dan pupuk NPK 16:16:16 sebanyak 20 gr/tanaman dengan hasil berat basah tanaman sebanyak 810,83 gr/tanaman dengan persentase peningkatan hasil sebesar 76,27\% dibandingkan tanpa pemberian sekam padi dan pupuk NPK 16:16:16. Sebagaimana yang diperlihatkan pada Gambar 6 dengan pemberian pupuk NPK dapat meningkatkan tinggi pertumbuhan bibit ketapang

Penambahan pupuk organik $40 \mathrm{~g}$ memberikan interaksi pada pertumbuhan ketapang seta penambahan tinggi, diameter, jumlah daun, dan berat kering tanaman seperti yang ditunjukan gambar 10. Kamaludin (2017) hasil pengukuran dan penghitungan diketahui bahwa perlakuan yang terbaik dalam memacu 
pertambahan jumlah daun dan tinggi anakan Salam adalah T4 (Kompos Kotoran Sapi dengan dosis 450 gram per anakan) dengan rerata pertambahan jumlah daun sebanyak 17,40 helai dan rerata pertambahan tinggi $15,00 \mathrm{~cm}$. Penelitian tersebut membuktikan semakin banyaknya jumlah kotoran sapi/pupuk organik yang diberikan memberikan pengaruh yang signifikan terhadap pertumbuhan tanaman.

Pertumbuhan dan perkembangan tanaman yang baik bila media tanam yang digunakan mempunyai kualitas yang baik dari segi sifat fisik, biologi, dan kimia tanah. Salah satu usaha agar media tumbuh tersebut dapat memberikan pertumbuhan yang baik bagi bibit adalah dengan pemberian pupuk NPK dan kotoran sapi. Pada dasarnya pertumbuhan dan perkembangan tanaman adalah hasil aktivitas metabolisme sel-selnya. Metabolisme tidak hanya menyediakan bahan baku untuk pertumbuhan dan perkembangan saja, tetapi juga menyediakan energi untuk semua proses yang terjadi di dalam tubuh tanaman khususnya pada bibit ketapang.

Berdasarkan hasil percobaan perbaikan media dengan penambahan pupuk NPK dan pupuk organik memberikan pengaruh yang sangat nyata terhadap pertumbuhan tinggi, diameter, jumlah daun dan berat kering bibit ketapang. Hasil penelitian ini sejalan dengan hasil penelitian yang dilakukan oleh Fiolita (2017) bahwa penggunaan pupuk NPK mutiara berpengaruh nyata dalam meningkatkan pertumbuhan tinggi, diameter dan jumlah daun tanaman gaharu (Aquilari spp) serta penelitian Irawan (2016) mengatakan bahwa penggunaan NPK dapat memberikan pengaruh yang nyata terhadap berat kering pertumbuhan (Shorea assamica Dyer) di persemaian. Semua perlakuan yang menggunakan pupuk NPK dan kotoran sapi memberikan hasil yang baik dibandingkan dengan perlakuan kontrol yang tanpa penambahan pupuk NPK dan kotoran sapi.

Penggunaan pupuk NPK dan pupuk organik sebagai pembenah tanah dan penyedia unsur hara yang lengkap. Semakin meningkatnya dosis pupuk, maka terjadi kenaikan pertumbuhan tinggi, diameter, jumlah daun dan berat kering bibit, hal ini disebabkan bahwa semakin dewasanya tanaman, maka sistem perakaran telah berkembang dengan baik dan lengkap, sehingga tanaman semakin mampu menyerap unsur hara makro dan unsur hara mikro dalam bentuk anion dan kation yang mengandung unsur hara. Semakin banyak jumlah unsur hara yang didapat diserap oleh tanaman, maka pertumbuhan dan perkembangan tanaman semakin meningkat. Sutedjo (2008), menyatakan bahwa untuk pertumbuhan vegetatif dan generatif tanaman diperlukan unsur-unsur hara terutama N, P dan $\mathrm{K}$.

Menurut Setyati dalam Sudjianto et al, (2009), pupuk NPK mempunyai peranan dalam memacu dan meningkatkan pertumbuhan dan hasil tanaman apabila aplikasinya tepat dan 
tidak berlebihan, karena dengan dosis yang tepat maka akan memberikan hasil yang optimal pada tanaman. Hal ini disebabkan karena unsur hara makro yang dikandung pupuk majemuk NPK memiliki peranan yang berbeda dalam proses metabolisme tumbuhan. Unsur N berperan dalam pembentukan klorofil yang bermanfaat dalam proses fotosintesis, apabila fotosintesis lancar maka semakin banyak karbohidrat yang akan dihasilkan. Unsur $\mathrm{P}$ berperan sebagai bahan dasar pembentukan ATP dan ADP yang dibutuhkan dalam proses metabolisme untuk pembentukan asam amino, tepung, lemak dan senyawa organik lainnya. Sedangkan unsur $\mathrm{K}$ berperan sebagai activator berbagai jenis enzim yang membantu pembentukan protein dan karbohidrat sekaligus memperkuat tubuh tanaman seperti daun, bunga dan buah sehingga tidak mudah gugur.

Menurut hasil penelitian yang dilakukan oleh (Wasis dan Noviani. 2010), menjelaskan bahwa pemberian pupuk kompos dan NPK pada media tailing dapat memperbaiki pertumbuhan tanaman. Pupuk organik memiliki banyak kelebihan dan ditambahkan secara langsung pupuk NPK sehingga ketersediaan unsur hara terpenuhi, pupuk organik memiliki unsur hara yang lengkap pada tanaman dapat pula memperbaiki sifat fisik, kimia dan biologi tanah, dengan memperbaiki struktur tanah, air serta meningkatkan aktivitas mikroorganisme tanah sedangkan pupuk NPK menyediakan unsur hara secara langsung yang dimanfaatkan oleh tanaman untuk melakukan pertumbuhan. Pupuk NPK menyediakan unsur hara secara langsung yang dimanfaatkan oleh tanaman untuk melakukan pertumbuhan dan pemberian pupuk NPK berpengaruh sangat nyata terhadap pertumbuhan tanaman gmelina. Penyuplaian pupuk NPK dapat meningkatkan unsur hara $\mathrm{N}, \mathrm{P}$, dan $\mathrm{K}$ yang membantu dalam pertumbuhan tanaman dikarenakan tailing memiliki pH yang asam. (Wasis dan Fatha. 2010).

Pemberian pupuk NPK dengan dosis $20 \mathrm{gr} / \mathrm{bibit}$ merupakan dosis yang terbaik sedangkan penggunaan dosis pupuk NPK lebih dari 0,5 gr/bibit menunjukkan respon pertumbuhan yang lebih rendah. Kecenderungan respon pertumbuhan bibit optimal dari penggunaan dosis pupuk NPK yang rendah dalam penelitian ini diduga karena media bibit yang digunakan telah mencukupi sebagian besar unsur hara yang dibutuhkan bibit.

Berdasarkan hasil analisis media dapat diketahui bahwa kandungan unsur $\mathrm{N}$ pada media bibit yang digunakan termasuk dalam kategori cukup tersedia sehingga dengan penambahan unsur $\mathrm{N}$ dengan dosis rendah pada media bibit telah mencukupi kebutuhan pertumbuhan bibit yang optimal. Wasis dan Fathia (2011) melaporkan bahwa penggunaan pupuk majemuk NPK akan memberi suplai $\mathrm{N}$ yang cukup besar ke dalam tanah. Hasil yang berbeda akan ditunjukkan apabila media bibit yang digunakan mempunyai kandungan unsur hara yang rendah. 
Hasil penelitian Junaedi (2012) melaporkan bahwa perlakuan pupuk NPK 2 gr/bibit yang dikombinasikan dengan kompos dan top soil pada media dengan kandungan unsur $\mathrm{N}$ rendah $(0,14)$ dapat meningkatkan pertumbuhan tinggi dan diameter rata-rata bibit asal cabutan. Hal ini memberi indikasi bahwa kandungan unsur $\mathrm{N}$ dalam jumlah yang berlebihan dalam media bibit ketapang akan memberikan dampak negatif bagi pertumbuhannya. Kurniawati dan Ariyani (2013) juga melaporkan bahwa pertumbuhan bibit menurun dikarenakan S. javanica kandungan unsur $\mathrm{N}$ pada media yang digunakan telah melampaui jumlah yang dibutuhkan untuk pertumbuhan bibit. Lebih lanjut Wasis dan Fathia (2011) menguraikan bahwa pengaruh penambahan unsur hara berupa pupuk NPK bergantung pada kondisi tanah dan kebutuhan tanaman dalam menyerap unsur hara.

Penggunaan pupuk sering menyebabkan gangguan terhadap pertumbuhan apabila dosis yang diberikan berlebih atau berkurang, pada waktu pemakaian yang kurang tepat, serta unsur yang diberikan tidak sesuai dengan kebutuhan tanaman.

Hasil sidik ragam menunjukan bahwa dari parameter pengamatan (tinggi, diameter, jumlah daun dan berat kering) tidak menunjukkan adanya perbedaan yang nyata, hal ini di duga bahwa masing-masing faktor perlakuan pada taraf perlakuannya tidak saling berinteraksi dan penggunaan pupuk NPK dan kotoran sapi tidak termanfaatkan secara sempurna.
Interaksi tidak terjadi disebabkan oleh pupuk NPK yang diberikan langsung termanfaatkan oleh tanaman sedangkan pemeberian pupuk kotoran sapi memerlukan waktu yang lama untuk bisa termanfaatkan sempurna oleh tanaman. Menurut Sutedjo dan Kartasapoetra (1987), bila salah satu faktor lebih kuat pengaruhnya dari faktor lain, maka faktor lainnya tertutupi.

\section{KESIMPULAN}

Hasil penelitian membuktikan bahwa pemberian pupuk NPK dan pupuk organik dapat meningkatkan pertumbuhan bibit ketapang di persemaian sampai umur 3 bulan. Pemberian pupuk NPK sebanyak $20 \mathrm{~g}$ menghasilkan peningkatan pertumbuhan terbaik yang diukur dari parameter tinggi, diameter, jumlah daun dan bobot berat kering bibit ketapang pada media tailing. Pemberian pupuk organik sebanyak 40 g menghasilkan peningkatan pertumbuhan terbaik yang diukur dari parameter tinggi, diameter, jumlah daun dan bobot berat kering bibit ketapang pada media tailing. Kombinasi pupuk NPK dan kotoran sapi 20:40 g menghasilkan peningkatan pertumbuhan terbaik yang diukur dari parameter tinggi, diameter, jumlah daun dan bobot berat kering bibit ketapang pada media tailing, dan dengan kombinasi pupuk NPK dan kotoran sapi tersebut dapat digunakan untuk memproduksi bibit Ketapang secara luas.

\section{DAFTAR PUSTAKA}

Ang LH. 1994. Problems and propects of afforestation on sandy tin tailings in Peninsular Malaysia. Journal of 
Tropical Forest Science 7(1):87105.

Direktorat Perbenihan Tanaman Hutan. 2001. Informasi Singkat Benih. Edisi 5. Jakarta: Departemen Kehutanan RI.

Ezeokonkwo AC dan Dodson WL. 2004. The Potential of Terminalia catappa L. (tripical almond) Seed as Source of Dietary Protein. Juornal Of Food Quality 27 : 207219.

Gaspersz V. 1991. Metode Perancangan Percobaan. CV.ARMICO. Bandung.

Irawan A dan Halawane J. E. 2016. Pengaruh Naungan dan Pupuk NPK Terhadap Pertumbuhan Shorea assamica Dyer. Di Perbibitan. Balai Penelitian dan Pengembangan Lingkungan Hidup dan Kehutanan Manado.

Junaedi A. 2012. Pengaruh Kompos dan Pupuk NPK Terhadap Peningkatan Kualitas Bibit Cabutan Shorea leprosula Miq. Journal Penelitian Hutan dan Konservasi Alam. Vol. 9, No. 4

Kamaludin. 2017. Pengaruh Pemberian Kompos Kotoran Sapi Terhadap Pertumbuhan Anakan Salam (Syzygium polyanthum) Di Persemaian. Journal. PIPER No.25 Volume 13 Oktober 2017.

Kurniawati F dan Ariyani M. 2013. Pengaruh Media Tanam dan Pemupukan NPK Terhadap Pertumbuhan Bibit Damar Matar Kucing (Shorea javanica). Journal Tanah dan Agroklimatologi. 10 (1) 2013.

Wasis B dan Fathia N, 2010. Pengaruh Pupuk NPK Dan Kompos
Rusdiana OY, Fakuara C dan Kusmana Y. Hidayat. 2000. Respon pertumbuhan tanaman sengon (Paraserianthes falcataria) terhadap kepadatan dan kandungan air tanah podsolik merah kuning. Jurnal Manajemen Hutan Tropika Vol 6 No. $2: 43$ 53.

Setyaningsih L. 2007. Pemanfaatan cendawan mioriza arbuskula dan kompos aktif untuk meningkatkan pertumbuhan bibit mindi (Melia azedarach Linn) pada media tailing tambang emas Pongkor. [Tesis] Bogor. Sekolah Pascasarjana IPB. Bogor.

Sudjianto, U. dan V. Krestiani. 2009. Studi dan dosis NPK pada hasil buah melon (Cucumis melo L.). Jurnal Sains dan Teknologi 2(2): 70-77.

Sutedjo M. 2008. Pupuk dan Cara Pemupukan. Rineka Cipta. Jakarta.

Sutedjo MM, Kartasapoetra. 1987. Pupuk dan Cara Pemupukan. Jakarta: Bina Aksara

Tamin RP. 2010. Pertumbuhan Bibit Jabon (Anthocephalus cadamba Roxb Mic) pada media pasca penambangan batu bara yang diperkaya fungi mikoriza arbuskula, limbah batubara dan pupuk NPK. [Tesis]. Sekolah Pascasarjana IPB. Bogor.

Vinny F, Muin A dan Fahrizal. 2017. Pengaruh Pupuk NPK Mutiara untuk Peningkatan Pertumbuhan Tanaman Gaharu Aquilaria spp pada Lahan Terbuka di Tanah Ultisol. Journal Hutan Lestari.

Terhadap Pertumbuhan Bibit Gmelina (Gmelina Arborea 
Roxb.) Pada Media Tanah Bekas Tambang Emas (Tailing). Journal

Wasis B dan Fathia, N. (2011). Pengaruh pupuk NPK terhadap pertumbuhan bibit gmelina (Gmelina arborea Roxb.) pada media tanah bekas tambang emas (tailing). Jurnal Silvikultur Tropika 2 (1), 14-18.

Wasis B dan Noviani, 2010. Pengaruh pemberian pupuk NPK dan kompos terhadap pertumbuhan bibit jabon (Anthocephalus cadamba Roxb Miq) pada media tanah bekas tambang emas (tailing). Jornal

Zein AM dan Zahrah S. 2013. Pemberian Sekam Padi dan Pupuk NPK Mutiara 16:16:16 pada Tanaman Lidah Buaya (Aloe barbadensis Mill.). Journal. Dinamika Pertanian Volume XXVIII Nomor 1 April 2013 (1-8). 